\title{
A agenda de segurança estadunidense no pós-Guerra Fria e o emprego das Forças Armadas na Argentina e no Brasil
}

USA security agenda after Cold War and the Armed Forces employment in Argentina and Brazil

\section{David Succi Junior ${ }^{1}$}

\section{RESUMO}

o presente trabalho tem como objetivo avaliar o modo como, no pós-Guerra Fria, o ímpeto estadunidense de envolver as Forças Armadas latino-americanas em atividades domésticas, com base na ideia de novas ameaças, foi absorvido por Argentina e Brasil. Busca-se, por meio de uma análise comparada, demonstrar como as especificidades das relações entre os civis e os militares em cada um dos países determinaram esse processo.

Palavras-chave: Forças Armadas; América do Sul; Novas ameaças.

\section{ABSTRACT}

The current paper aims to evaluate the way in which the USA impetus after the Cold War to engage the Latin American Armed Forces in domestic activities, based on the idea of new threats, was assimilated by Argentina and Brazil. It seeks, with a comparative analysis, to demonstrate how the specific features of civil-military relations in each country determined this process.

Key-words: Armed Forces; South America; New Threats.

\section{INTRODUÇÃo}

0 presente trabalho tem como proposta analisar a tentativa estadunidense de influenciar o tipo de missões e funções a serem atribuídas aos militares latino-americanos no pós-Guerra Fria. A questão posta refere-se à indicação de que as Forças Armadas da região, finda a ameaça comunista, deveriam ser direcionadas a problemáticas internas, como o combate ao narcotráfico. Busca-se compreender o resultado desse discurso securitizador nos países do Cone Sul a partir de um estudo comparado dos casos

\footnotetext{
${ }^{1}$ Mestrando em Relações Internacionais pelo Programa de Pós-graduação em Relações Internacionais San Tiago Dantas (Unesp-Unicamp-PUC-SP), São Paulo, Brasil. Bolsista do CNPq. 
argentino e brasileiro. No primeiro, observa-se, com o fim do regime militar, a construção de uma rígida delimitação entre defesa externa e segurança pública, o que notadamente indica um não alinhamento ao discurso estadunidense. No segundo caso, nota-se um acentuado emprego militar em questões de segurança interna, sendo, porém, reducionista atribuí-lo exclusivamente ao ímpeto securitizador oriundo dos Estados Unidos. Como indica Balzacq (2005), a securitização não pode ser entendida como um instrumento objetivo que responde de modo claro aos interesses do agente que a emprega, uma vez que está limitada pelo contexto em que se estabelece.

A penetração estadunidense no Cone Sul será abordada nos termos postos por Haacke (2009). Apesar de o objeto de estudo desse autor ser a influência do poder de grandes potências em dinâmicas regionais, as classificações que ele propõe podem ser apropriadas para analisar processos referentes a Estados. Haacke afirma que, de modo geral, há dois polos de penetração de grandes potências em uma região: os casos em que o poder de influência das forças externas é maior do que o das internas e as ocasiões em que as dinâmicas internas predominam sobre os impulsos extrarregionais. Ele indica, então, três tipos de resposta aos estímulos externos: resistência explícita, acomodação estratégica e suporte explícito. Defende-se a hipótese de que a Argentina encontra-se na primeira classificação, enquanto o Brasil aloca-se entre as duas primeiras. Deve-se pontuar, porém, que a definição do âmbito de emprego dos meios militares nos países estudados não representa uma mera reação à pauta estadunidense, mas consiste em um complexo processo político no qual o discurso securitizador extrarregional aqui analisado constitui apenas um aspecto a ser considerado.

A investida estadunidense em influenciar a região é entendida como um discurso que busca militarizar a segurança pública, sendo aqui tratado como um discurso securitizador. Para entender a maior ou menor aderência a ele serão apresentados os contextos históricos em que se encontrava cada um dos países analisados. Parte-se do pressuposto de que a realidade constrói-se a partir das interações entre os agentes sociais, os quais criam e, ao mesmo tempo, são restringidos por normas sociais. Não há, portanto, precedência ontológica entre agente e estrutura. Esse ambiente social que se constitui de forma tão complexa determina, por um lado, a posição daquele que enuncia, ou seja, garante maior ou menor legitimidade para determinado agente. Por outro, delimita a possibilidade de sucesso da securitização, pois, como defendido por Balzacq, o 
discurso securitizador deve ressoar determinados elementos que a audiência percebe na realidade.

Desse modo, as especificidades da transição do regime burocrático-autoritário para a democracia na Argentina constituíram um momento de reestruturação de percepções e normas - o que garantiu espaço discursivo a determinada comunidade epistêmica, como indicado por Vitelli (2015) -, as quais negaram a perspectiva de emprego interno das Forças Armadas, em detrimento de grupos internos que a defendiam (SAIN, 2001). No Brasil, por sua vez, a transição controlada pelos militares permitiu a perpetuação da concepção, que nasceu com o próprio Estado, de que cabe aos fardados a garantia da lei e da ordem (MATHIAS, 2010).

Com base na presente análise, defende-se que as especificidades das dinâmicas internas a cada um dos países estudados, vinculadas à relação entre os militares e o Estado, determinaram o modo como o discurso externo foi absorvido por Brasil e Argentina. Na primeira seção, deve-se apresentar a perspectiva teórica formulada por Balzacq acerca do discurso como instrumento de securitização. Com base nessa concepção, devem-se, em um segundo momento, definir as características e os objetivos do discurso securitizador estadunidense em relação à América Latina no pós-Guerra Fria. Para avaliar o resultado do ímpeto externo, busca-se definir em que consiste o atual padrão de emprego dos militares na Argentina e no Brasil. Por fim, definem-se a audiência e seu contexto, a fim de compreender o modo como o discurso externo foi absorvido.

\section{SECURITIZAÇÃO: AGENTE E AUDIÊNCIA}

O conceito de securitização foi desenvolvido pela Escola de Copenhague (EC), mais notadamente por Ole Wæver. Nessa perspectiva, atribui-se ao ato de fala o centro explicativo de um processo que confere a determinada temática o caráter de segurança, transferindo-a da esfera do não politizado para o securitizado, passando pelo politizado. A prática discursiva não é mais entendida como uma descrição da realidade material objetiva, mas como um elemento de agência, de construção do sentido social e, consequentemente, da própria realidade. Os autores afirmam que a securitização é o máximo da politização, uma vez que leva ao campo da excepcionalidade, a qual, por sua vez, é legitimada diante de uma ameaça à existência do objeto a ser assegurado. 0 agente securitizador, em seu ato de fala, enuncia uma ameaça existencial, e o processo completa- 
se quando certa audiência anui a ele. É durante esse processo, portanto, que se constrói um elemento a ser combatido. Nessa perspectiva, o inimigo não constitui um elemento presente de modo objetivo na realidade que deve ser desvelado, mas sua própria existência depende do ato de fala (BUZAN; WFVER; WILDE, 1998).

Deve-se ponderar, porém, que não há uma relação automática entre a designação do inimigo e os meios pelos quais ele deve ser combatido. Evidentemente, serão designados os instrumentos de violência do Estado, porém o ponto sensível do presente trabalho refere-se justamente à decisão de se utilizar o aparato de segurança pública ou de defesa. Entende-se aqui que o emprego da violência militar está vinculado à ideia de ameaça existencial ao Estado, oriunda da atuação das Forças Armadas convencionais. Refere-se à ameaça nos termos postos por Saint-Pierre (2007), ou seja, um sinal que não necessariamente corresponde à realidade que anuncia. Para o autor, a ameaça constituise no e para o receptor, de modo que se estabelece a partir de sua recepção e pode representar um instrumento político-estratégico cujo fim é o de gerar um tipo específico de mobilização. Desse modo, ainda que o Estado não se encontre sob um risco existencial, a securitização e a decisão de empregar os meios militares para combater determinada ameaça dependem de um discurso que indique o perigo à existência do objeto a ser assegurado e que produza certo sinal, a ser aceito por determinada audiência.

Balzacq reconhece o mérito da EC e, com o intuito de fortalecer a agenda de pesquisa, problematiza seu conceito de securitização. 0 autor considera tal perspectiva demasiadamente formalista, o que reduziria um processo social complexo a um mero procedimento, considerando a audiência como um elemento passivo, e não atribuindo o devido peso aos fatores contextuais. Nesse sentido, o autor afirma que, por meio da ideia de ato de fala, a EC objetiva encontrar elementos universais de comunicação para explicar o processo de securitização. Balzacq propõe uma análise desse processo a partir de uma perspectiva pragmática, ou estratégica, do ato de fala, na qual o agente que enuncia utilizase de inúmeros artifícios, com base na compreensão que tem da audiência-alvo, a fim de lograr sucesso em seu objetivo. Por compreender a prática discursiva como um instrumento, divide-a em três atos: locutionary, illocutionary e prelocutionary, os quais resume citando Habermas (1984 apud BALZACQ, 2005, p. 175, grifo do autor): "To say something to act in saying something, to bring about something through acting in saying something". 
Com base nessa visão instrumental, o autor afirma que, assim como a EC, reconhece que o emprego da palavra segurança altera o contexto, porém, segundo Balzacq, para atingir o objetivo aspirado, essa utilização deve estar ajustada a um contexto externo, independentemente do uso da linguagem. 0 ato de fala não se torna efetivo ex opere operato, ou seja, não se verifica automaticamente por sua mera execução, pela força do próprio rito, de modo independentemente do receptor. Dessa forma, o elemento contextual torna-se central para o autor, uma vez que considera a audiência como uma força viva, e não como um fator meramente passivo no processo de securitização. É com base nessa perspectiva que se busca aqui compreender os obstáculos ao discurso estadunidense nos países estudados.

\section{AGENDA DE SEGURANÇA ESTADUNIDENSE PARA A AMÉRICA DO SUL: O DISCURSO SECURITIZADOR}

Faz-se necessário indicar em que consiste o discurso securitizador estadunidense para a região estudada, o qual não apenas indica a problemática a ser securitizada, mas prevê também os meios a serem empregados para lidar com essa região. 0 ímpeto estadunidense em estabelecer a América Latina como sua zona de influência, por meio de imposição de modelos político-econômicos ou estratégicos, é uma constante desde o século XIX, marcado pela Doutrina Monroe (MALATIAN, 2007). Para Santos (2007, p. 19),

\footnotetext{
De um modo geral, pode-se dizer que os interesses norte-americanos na região sempre se moveram de acordo com as suas preocupações em relação à segurança nacional, às políticas domésticas e aos interesses econômicos de suas grandes empresas, configurando uma história de mudanças periódicas cíclicas, com continuidades e modificações, dependendo de variáveis como o volume de negócios, o grau de adesão das elites latino-americanas, a resistência de vários segmentos sociais latino-americanos, a importância de um determinado país no sistema de segurança hemisférica, etc.
}

Para os fins deste trabalho, serão apresentadas a homogeneização estratégica lograda pelos Estados Unidos na região durante a Guerra Fria, com base na Doutrina de Segurança Nacional (DSN), e a busca por mantê-la após o fim das tensões Leste-Oeste, pautando-se na ideia de multidimensionalidade, ligada às então denominadas novas ameaças.

No contexto da Guerra Fria, em que as relações no sistema internacional pautavam-se pela disputa entre dois modelos político-econômicos representados pelos 
Estados Unidos, de um lado, e pela União Soviética, de outro, o ímpeto estadunidense em garantir seu poder de influência na América Latina baseou-se na DSN, cuja presença na onda de ditaduras militares que se estabeleceu na América do Sul entre as décadas de 1960 e 1970 é notável. A DSN tinha como pressuposto central o conflito global entre o Ocidente e o comunismo soviético, constituído por duas facetas: a ameaça de agressão externa por parte da União Soviética e a subversão interna. Cria-se assim um inimigo interno a ser combatido, que se traveste de cidadão nacional, cujo resultado direto é a fusão entre as esferas da defesa e da segurança pública. Nesse contexto, há "uma espécie de divisão internacional do trabalho militar do Ocidente, cabendo às forças armadas latino-americanas tarefas essencialmente policiais" (MIGUEL, 1999, p. 43). Logrou-se, assim, a homogeneidade estratégica da região.

É comum a perspectiva de que a DSN corresponde a uma cartilha produzida no National War College, em Washington, e "exportada pelos Estados Unidos para consumo das forças armadas sul e centro-americanas" (MIGUEL, 1999, p. 43). Garcia (1997), ao analisar o pensamento militar brasileiro em política internacional durante o regime autoritário, questiona essa perspectiva, a qual denomina de interpretação crítica tradicional. Segundo o autor, essa vertente superestima o poder de influência estadunidense, desconsiderando as múltiplas visões que se faziam presentes no interior das Forças Armadas, além da autonomia decisória brasileira. Ele afirma ainda que o golpe de 1964 foi impulsionado por uma dinâmica interna ligada a um grupo específico do Exército, com o objetivo de implementar um projeto de nação elaborado na Escola Superior de Guerra (ESG). Feita a devida ponderação, para o objetivo do presente trabalho, destaca-se que a perspectiva da DSN convergia com o posicionamento estadunidense para a região, sobrepondo as funções de segurança pública e defesa externa.

O fim da Guerra Fria, caracterizado pela dissolução da União Soviética, constituiu um ponto de reestruturação da conjuntura sistêmica global, uma vez que cai por terra a tensão Leste-Oeste que havia pautado até então todas as relações no cenário internacional. Os anos que sucederam o fim da bipolaridade no sistema internacional são caracterizados por uma forte intensificação dos processos de globalização, em especial da economia, refletindo um aumento da porosidade das fronteiras nacionais e dos fluxos e atores transnacionais. 
O surgimento da ideia de novas ameaças está diretamente relacionado ao processo de intensificação das práticas transnacionais na nova configuração global. Essa expressão, como aponta Lopez (2003), é empregada para assuntos não necessariamente novos, mas que, inseridos nessa mudança de conjuntura, ocorrida entre o final da década de 1980 e o início de 1990, passaram a ser considerados ameaças aos Estados e suas sociedades. Tais ameaças são caracterizadas por não se enquadrarem nas concepções convencionais, ou seja, não são oriundas de forças militares estatais de fácil identificação, cujo âmbito de ação está em certa media previsto. As mais recorrentemente citadas são: narcotráfico, crime organizado internacional, tráfico de armas, terrorismo, degradação do meio ambiente, fundamentalismos religiosos, migrações e pobreza extrema. Em face dessas questões de caráter não estatal e internacional, tem-se uma crescente dificuldade em diferenciar as ações internas das externas, ou seja, em definir quais questões, quando estas exigem emprego da força, são de caráter policial e quais são características da atuação militar. Ampliam-se, desse modo, as denominadas ações constabulares, constituídas de atividades que se encontram na intersecção das esferas policial (interna) e militar (externa). "Correspondem geralmente ao emprego de forças intermediárias" (MEDEIROS, 2010, p. 42).

A novidade, portanto, das novas ameaças relaciona-se à alteração no processo de percepção delas, influenciada pela alteração conjuntural no sistema internacional.

Nesse contexto é criada, no âmbito da Organização das Nações Unidas (ONU), a Comissão Palme, com a função de avaliar as ameaças que poderiam emergir na nova conjuntura internacional, atribuindo a essas o adjetivo multidimensional. Segundo SaintPierre, a multidimensionalidade onusiana foi introduzida no continente americano pela Conferência de Ministros de Defesa das Américas, obedecendo ao objetivo estadunidense de transformar a América em sua área de segurança nacional, mantendo a homogeneização estratégica que impuseram ao continente durante a Guerra Fria. Assim,

\footnotetext{
Com esse objetivo, é formulada a convocação das Conferências de Ministros de Defesa das Américas (CMDAs), como foro para discutir as questões da área e, especialmente, tratar de aprovar uma agenda hemisférica de segurança (...). A lista de ameaças propostas respeitava mais ou menos aquelas levantadas pela Comissão Palme, todavia, a ordem de prioridade ou de "periculosidade" respondia basicamente às necessidades norte-americanas (SAINT-PIERRE, 2011, p. 410).
} 
Em 2003, sob a égide da OEA, conformou-se o acordo de Bridgetown, no qual se consolidou o conceito de ameaça multidimensional, que, por um lado, reafirma o caráter transnacional das novas ameaças e, por outro, indica que estas podem estar ligadas a fenômenos políticos, econômicos e sociais (MANAUT, 2006). De acordo com Barrachina e Rial (2006), apesar de o conceito, por si só, não implicar o emprego dos meios militares para lidar com essas ameaças, abre-se espaço para a militarização de assuntos internos. Deve-se considerar que a agenda de segurança estadunidense para a região prevê a militarização de questões relativas à segurança pública (HERZ, 2002). Tem-se então a percepção da ameaça, por um lado, e a indicação de uma agenda estratégica para lidar com ela, por outro.

Ao analisar a ideia de multidimensionalidade na agenda de defesa hemisférica, Saint-Pierre (2012) afirma que esta não corresponde às características centrais de um conceito. Afirma que a maior virtude de um conceito é sua capacidade analítica, indicando então que a etimologia da palavra análise, oriunda do grego, refere-se ao ato de separar, dissolver, diluir uma substância ou um tópico a fim de identificar seus elementos constituintes. A multidimensionalidade, por outro lado, ao misturar elementos de natureza diversa - e que, portanto, requerem respostas diversas -, não possibilita a compreensão e a explicação satisfatórias do fenômeno, impossibilitando a proposição de soluções eficientes para ele. "Pero tal vez lo más peligroso de este concepto sea el aprovechamiento político de la confusión que esta multidimensionalidade mal explicada permite" (SAINT-PIERRE, 2012, p. 21, grifo do autor).

O perigo do aproveitamento político, indicado pelo autor, está relacionado ao modo como ele define ameaça. Como já citado neste trabalho, para Saint-Pierre, a ameaça não constitui um objeto, mas, sim, uma relação entre o emissor e o receptor. Desse modo, a agenda de segurança, assim como o processo de conhecimento para Berger e Luckmann (2009, p. 99), refere-se "ao que é socialmente definido como realidade e não a critérios extrassociais de validade cognoscitiva". Nesse sentido, Saint-Pierre afirma que a matéria que constitui a segurança internacional é a percepção. Ademais, com base nessa concepção, defende-se o que foi anteriormente indicado: que não há uma relação automática entre a ameaça percebida e os recursos empregados para combatê-la. Assim como a ameaça, a decisão político-estratégica de empregar as Forças Armadas no combate às novas ameaças, ou seja, o processo de militarização dessas questões, é estabelecida por meio de uma construção social, da estruturação de uma significação específica, da qual o 
discurso estadunidense aqui analisado é parte integrante. A temática do narcotráfico é, nesse sentido, central para pensar a região no pós-Guerra Fria.

0 tráfico de drogas ilícitas é caracterizado como ameaça aos Estados Unidos ainda durante o período da Guerra Fria, quando Richard Nixon (1969-1974), caracterizou a atividade como ameaça à sociedade estadunidense e declarou "guerra às drogas". Ronald Reagan (1981-1989) e George H. W. Bush (1989-1993) reafirmaram e ampliaram a classificação feita por Nixon, indicando o tráfico de drogas como ameaça não apenas à segurança nacional dos Estados Unidos, mas também a todos os países do hemisfério nos quais tal atividade estivesse presente. Segundo Herz (2000), o combate ao comércio de drogas ilícitas foi o carro-chefe da relação dos governos de Bush e Bill Clinton (19932001) com a região.

0 posicionamento do ex-subsecretário estadunidense para Assuntos Interamericanos Michael Skol (1993-1996) sinteriza tal posicionamento:

Las Fuerzas Armadas [latinoamericanas] pueden contribuir com sus destrezas y
capacidades para complementar los esfuerzos en la aplicación de las leyes. Los
militares pueden proporcionar servicios de inteligencia, trasporte y logística;
pueden controlar rios, costas y espacio aéreo. Además, pueden ayudar a los
organismos de aplicación de la ley [policías y fuerzas de seguridad] a actuar más
directamente donde se encuentran concentrados los narcotraficantes y los
laboratorios (...). Los líderes civiles y militares han llegado a la conclusión de que
los narcotraficantes representan uma de las grandes amenazas a las
instituiciones democráticas de un país (DIARIO CLARÍN apud SAIN, 2001, p. 15).

Segundo Sanahuja e Verdes-Montenegro (2014), a guerra contra as drogas assumiu o posto de objeto principal da segurança nacional estadunidense, substituindo o combate anticomunista. Para os autores, as mudanças verificadas a partir do fim da Guerra Fria e os processos de redemocratização influenciaram as alterações de função das Forças Armadas da região, e o progressivo aumento do emprego delas no combate ao narcotráfico corresponde à política estadunidense de securitização das drogas e à consequente militarização dos meios para lidar com sua venda ilícita. Essa militarização, segundo os autores, significou, em muitos casos, um obstáculo à democratização, cujo pressuposto central é a desmilitarização da segurança pública.

Em síntese, o discurso securitizador estadunidense para a América do Sul no pósGuerra Fria - objeto central da análise aqui proposta - é caracterizado pela tentativa de influenciar os países da região a empregar as Forças Armadas em atividades de segurança 
pública. Fundamentado no conceito pouco claro de ameaça multidimensional, o discurso em questão visa a uma homogeneização estratégica da região, similar àquela obtida durante a Guerra Fria. Na próxima seção pode-se notar que tal homogeneidade ambicionada não se observa no atual padrão de emprego dos meios militares argentinos e brasileiros.

\section{ATUAL PADRÃO DE EMPREGO DOS MILITARES NO BRASIL E NA ARGENTINA}

Com o objetivo de compreender de que forma o discurso securitizador estadunidense, nos termos indicados na seção anterior, teve efeito no emprego das Forças Armadas na região, mais especificamente nos casos argentino e brasileiro, faz-se necessário indicar em que consiste o atual padrão de emprego dos militares nesses países, ou seja, para quais atividades estes são mais comumente mobilizados. Para tanto, realizaram-se levantamento, leitura e sistematização dos informes semanais, relativos a Argentina e Brasil, produzidos pelo Observatório Sul-Americano de Defesa e Forças Armadas entre os anos de 2005 e 2015. Produto do Grupo de Estudos de Defesa e Segurança Internacional (Gedes), sua produção tem como fonte periódicos de grande circulação nacional: Clarín, La Nación e Página 12, na Argentina; Folha de S.Paulo, O Estado de S. Paulo e Correio Braziliense, no Brasil. Um dos principais objetivos do trabalho realizado pelo grupo é a criação de um banco de dados de fácil acesso para a realização de pesquisas acadêmicas. Os informes são constituídos de resumos das notícias selecionadas durante cada semana, sendo que cada resumo pode conter uma ou mais notícias sobre a mesma temática. É importante destacar que o esforço de sistematizar tais dados não objetiva representar um levantamento quantitativo preciso das ações militares, e sim indicar os principais âmbitos de ação dos meios castrenses. Deve-se indicar ainda que foram considerados os resumos relativos às atuações específicas, não sendo contabilizados os editoriais e as colunas opinativas. 0 resultado da sistematização está ilustrado nas tabelas 1 e 2 . Os principais temas envolvendo o emprego militar nesse período foram: defesa de recursos estratégicos e do território, defesa civil, segurança pública, missões de paz, obras públicas e saúde pública.

No Brasil, nota-se uma nítida proeminência dos assuntos ligados à segurança pública: $46 \%$ dos resumos selecionados são relativos a tal âmbito de atuação. A segunda temática com maior número de resumos computados refere-se à participação em missões 
de paz da ONU, representando 35\% do total. Defesa de recursos estratégicos e do território - função convencional das Forças Armadas - é o terceiro âmbito de atuação com maior número de resumos: 15,34\%. É importante notar que a soma das temáticas obras pública, saúde pública e defesa civil, ou seja, ações subsidiárias relativas ao âmbito doméstico, representa 17,33\% do total dos resumos considerados. A soma das temáticas relativas a assuntos internos, cuja competência é de outros órgãos estatais, mas que contam com o emprego dos militares devido à consideração de que esses outros instrumentos do Estado não são capazes de lidar satisfatoriamente com elas, como segurança pública, saúde pública, obras públicas e defesa civil, representa 65,34\% do total dos dados obtidos.

\section{TABELA 1 - Emprego das Forças Armadas no Brasil (2005-2015)}

\begin{tabular}{|c|c|c|c|c|c|c|c|c|c|c|c|c|}
\hline \multirow[t]{2}{*}{ Áreas de atuação } & \multicolumn{12}{|c|}{ Número de informes } \\
\hline & 2005 & 2006 & 2007 & 2008 & 2009 & 2010 & 2011 & 2012 & 2013 & 2014 & 2015 & Total \\
\hline Missões de paz & 30 & 11 & 6 & 9 & 2 & 15 & 16 & 7 & 3 & 3 & 5 & 107 \\
\hline Segurança pública & 19 & 16 & 25 & 18 & 7 & 8 & 15 & 33 & 41 & 40 & 9 & 231 \\
\hline Obras públicas & 3 & 3 & 2 & 1 & 3 & - & 10 & 3 & 2 & - & - & 27 \\
\hline Defesa civil & 1 & 1 & 1 & 2 & 9 & 5 & 2 & 1 & 6 & 3 & 5 & 36 \\
\hline Saúde pública & 3 & - & - & 4 & 4 & - & 1 & 3 & 3 & 1 & 5 & 24 \\
\hline $\begin{array}{l}\text { Defesa de recursos } \\
\text { estratégicos/ } \\
\text { território }\end{array}$ & 3 & 4 & 8 & 14 & 7 & 08 & 6 & 13 & 10 & 2 & 2 & 77 \\
\hline Total & 59 & 35 & 42 & 48 & 32 & 36 & 50 & 60 & 65 & 49 & 26 & 502 \\
\hline
\end{tabular}

Fonte: o autor (2016).

Na Argentina, por outro lado, o emprego das Forças Armadas em atividades convencionais representa $42,7 \%$ dos resumos selecionados, sendo a participação em missões de paz a segunda atividade com maior número de resumos, 34,95\%. Segurança pública, que no Brasil apresenta-se com grande proeminência em relação aos outros âmbitos de atuação, representa, no país vizinho, apenas 5,85\% dos resumos no mesmo período. A soma de outras atividades internas, como saúde pública, defesa civil e obras públicas, ultrapassa o emprego em segurança pública, retratando 16,5\% do total. Desse modo, pode-se afirmar que o emprego da força pelos instrumentos militares argentinos restringe-se a atuações externas, âmbito que representa $82,4 \%$ dos dados sistematizados. Nas atividades excepcionais de emprego interno, a utilização da força, ou seja, as ações de segurança pública, representa um número reduzido. 
TABELA 2 - Emprego das Forças Armadas na Argentina (2005-2015)

Áreas de atuação

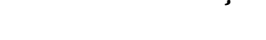

Missões de paz

Segurança pública

Obras públicas

Defesa civil

Saúde pública

Defesa de recursos

estratégicos/território

Total

Fonte: o autor (2016).

\section{Número de informes}

$\begin{array}{cccccccccccc}2005 & 2006 & 2007 & 2008 & 2009 & 2010 & 2011 & 2012 & 2013 & 2014 & 2015 & \text { Total } \\ 3 & 6 & 3 & 4 & 4 & 4 & 2 & 2 & 2 & 2 & 4 & 36 \\ - & 1 & - & - & - & - & - & 5 & - & - & - & 6 \\ - & - & - & - & - & - & - & - & - & 3 & - & 3 \\ - & 1 & 1 & - & - & 2 & - & - & 3 & - & 2 & 9 \\ - & - & - & 1 & 2 & - & 1 & 1 & - & - & - & 5 \\ 3 & - & 1 & 5 & 2 & 6 & 5 & 10 & 6 & 3 & 3 & 44 \\ 6 & 8 & 5 & 10 & 8 & 12 & 8 & 18 & 11 & 8 & 9 & 103\end{array}$

\section{CONSTRUÇÃO DO CONTEXTO BRASILEIRO E ARGENTINO: A AUDIÊNCIA}

Definidos o discurso securitizador estadunidense e o padrão de emprego das Forças Armadas que se observa atualmente na Argentina e no Brasil, deve-se então, em concordância com o modelo analítico de Balzacq, definir em que consiste a audiência.

Do mesmo modo que o discurso não é entendido como a descrição de uma realidade objetiva, o contexto ao qual fazemos referência, e que impõe limitações ao discurso securitizador, é aqui verificado no âmbito ideacional. Tem-se como foco, portanto, o sentido atribuído à realidade. Para os fins do presente trabalho, cabe analisar o sentido atribuído ao aparato militar. Para tanto, faz-se necessária uma retomada histórica da relação entre os meios castrenses e o Estado. Deve-se considerar ainda que, desde a fundação dos países analisados, os fardados assumiram a posição de agente político. Desse modo, influenciaram, e talvez determinaram, certas decisões dos governantes civis, aos quais deveriam servir de instrumento. Tiveram, desse modo, condições de fazer valer o significado que atribuíram a si próprios. Assim, analisar a relação entre as Forças Armadas e o Estado na Argentina e no Brasil requer a compreensão do grau de controle civil exercido sobre os militares em cada período. Diante dessas considerações, pode-se afirmar que a audiência-alvo do discurso securitizador estadunidense para a região é constituída tanto pelos governos civis quanto pelas lideranças militares. 
A análise terá como base a perspectiva teórica de Kowert e Legro (1996), para os quais os elementos que constituem a ação social são dois: as normas e a identidade dos atores. Normas são definidas como regras de comportamento, leis, costumes, hábitos que regulam a cultura política. Identidade, por sua vez, é compreendida pelos autores como o conteúdo normativo interno aos indivíduos. Desse modo, buscamos argumentar que a estrutura social interna a cada um dos países estudados, que obstaculou a consecução do discurso securitizador estadunidense para a América Latina, foi historicamente construída no interior de cada um dos Estados a partir da relação e coconstrução entre normas e identidades, estrutura e agentes, não havendo precedência ontológica entre eles. Os atores cuja identidade é fundamental para a compreensão do processo aqui analisado são os militares, além do sentido atribuído a eles pelo governo civil.

\section{MALOGRO DA SECURITIZAÇÃO}

A fim de compreender a formação da audiência definida na seção anterior, buscase aqui apresentar um breve panorama do desenvolvimento da relação entre os militares e o Estado, mais especificamente sobre a compreensão acerca do papel a ser desempenhado pelas Forças Armadas.

Como indicado por Rouquié (1982, p. 123), "são os problemas internos, os perigos domésticos, sociais ou políticos que solicitam propriamente a ação militar das forças armadas latino-americanas". Mais especificamente sobre os países analisados pelo presente trabalho:

\footnotetext{
No Brasil - onde os oficiais desconhecem as guerras desde a do Paraguai, que terminou em 1870 e, sem remontar às emoções regionais que pontuaram o passado imperial, com rebeliões como a da Sabinada na Bahia em 1837, ou as revoltas Praieira e Farroupilha de Pernambuco e do Rio Grande do Sul de 1840 e 1850 - foi o Exército que esmagou, não sem alguma dificuldade, as rebeliões camponesas do Contestado e de Canudos. 0 Exército argentino nunca teve outros inimigos além dos índios reprimidos no Sul e pacificados no Norte nos anos trinta, dos metalúrgicos de Buenos Aires em 1919, dos trabalhadores temporários agrícolas da Patagônia em 1920 e dos anarquistas vindos da Europa (ROUQUIÉ, 1982, p. 123).
}

Com base nessa breve passagem, tem-se a intenção de indicar a concepção de emprego e o autoentendimento dos militares argentinos e brasileiros desde a fundação desses Estados. 0 inimigo a ser combatido esteve durante toda a história desses países majoritariamente no âmbito doméstico. Além da atuação para conter movimentos 
internos, deve-se destacar que os fardados de ambos os países atribuíram historicamente a si próprios a competência de garantir a normalidade institucional e a modernização do Estado, o que se manifestou em recorrentes intervenções militares, cuja representação mais bem acabada são os governos burocrático-autoritários que se estabeleceram na região entre as décadas de 1960 e 1980. Desse modo, o desenvolvimento da relação entre os militares e o Estado nesses países reafirmou normas e identidades militares que cristalizam a concepção de emprego interno e atuação política das Forças Armadas.

O fim das ditaduras militares, com a transição para regimes democráticos nos dois países, tem papel central para o entendimento do contexto interno em que ambos receberam o discurso securitizador analisado no presente trabalho. Foi esse processo histórico que permitiu, na Argentina, sem desconsiderar as resistências e os obstáculos encontrados, uma revisão da concepção acerca das missões a serem atribuídas aos militares, marcada por iniciativas que objetivaram alterar a identidade militar no país. A transição constituiu um momento em que a agência de determinado grupo de atores logrou a alteração das normas até então vigentes (LOPEZ, 2007). No Brasil, por outro lado, as especificidades da transição para a democracia, que ocorreu de forma quase administrativa (SOARES, 2006), garantiram a continuidade da identidade militar e da concepção acerca do emprego das Forças Armadas.

Na Argentina, houve inicialmente a pretensão de executar a transição do regime militar (1976-1983) para o governo civil de maneira pactuada. Porém, com a derrota do país na Guerra das Malvinas, intensificou-se a falta de apoio da sociedade civil ao governo militar, inviabilizando o ímpeto inicial. Deve-se, porém, ponderar que a peculiaridade da redemocratização argentina consiste no fato de que "não houve finalmente um pacto, mas tampouco houve uma completa derrota política dos militares e plena ocupação dos espaços e recursos de poder por parte dos civis (...)" (LOPEZ, 2007, p. 21). Desse modo, é possível compreender as vicissitudes da transição política da Argentina, marcada pela resistência dos meios castrenses à consolidação do controle civil objetivo. ${ }^{2}$ A passagem do governo militar para o civil na Argentina foi também caracterizada pelo descontentamento em relação às medidas de repressão executadas pelos militares. Ao longo de todo o Processo de Reorganização Nacional (PRN), como o governo castrense

\footnotetext{
2 Entendido como a maximização do poder civil sobre os militares, com base na profissionalização dos últimos (HUNTINGTON, 1957).
} 
autodenominou-se, a repressão matou entre 16 mil e 21 mil pessoas (SAIN, 2000, p. 22). Ademais, deve-se considerar o desgaste interno à corporação militar.

Desses elementos, podem-se depreender inúmeras consequências. Porém, para os fins deste trabalho, daremos ênfase às implicações para a delimitação das tarefas militares. Foi durante o mandato de Raúl Alfonsín (1983-1989), primeiro governo civil após o regime militar, que se estabeleceu a Lei $\mathrm{n}^{\circ} 23.554 / 88$, conhecida como Lei de Defesa Nacional. A norma é considerada um marco por representar a eliminação da DSN, que havia conduzido "a uma fusão das missões de segurança e defesa" (LOPEZ, 2007, p. 18) no interior das instituições militares.

Por um lado, a lei estabeleceu uma clara distinção entre defesa nacional e segurança interna. As ameaças externas, atribuídas à defesa nacional, são entendidas como "aquelas perpetradas pelas Forças Armadas regulares de um Estado contra o território de outro Estado" (SAIN, 2003, p. 163). São, portanto, definidas pelo tipo de agressor e de agressão. Por outro, circunscreveu as tarefas militares exclusivamente às questões de defesa. A clara distinção entre esses dois âmbitos consolidou-se com a Lei de Segurança Interna, estabelecida durante o governo de Carlos Menem (1989-1998). A norma atribui as principais responsabilidades da segurança interna às polícias e às guardas nacional e costeira, ficando as Forças Armadas com um papel secundário de apoio em situações excepcionais, seguindo determinação das autoridades civis.

Deve-se considerar que, como apontou Sain (2003), entre a década de 1990 e o início dos anos 2000, houve na Argentina, em decorrência das discussões internacionais acerca das novas ameaças e das indicações estadunidenses de empregar os militares no combate ao narcotráfico, certa pretensão por parte de alguns grupos em reviver a participação castrense em assuntos de segurança pública. Apesar desses ímpetos, as Forças Armadas continuam sendo consideradas forças de atuação externa. Tal concepção perde força com a sanção da Lei de Inteligência Nacional, em 2001.

No Brasil, como já indicado anteriormente, o Exército surgiu como força “(...) de ocupação colonial, cujo inimigo a combater estava no próprio território, indicando para sempre sua função - não defesa contra inimigos externos, mas, sim, uma força de garantia da ordem vigente" (MATHIAS, 2003, p. 126). Em todas as constituições brasileiras, exceto 
as de 1824 e 19373, são atribuídas três funções às Forças Armadas: a defesa nacional, a garantia dos poderes constitucionais e a manutenção da lei e da ordem interna. Durante o regime militar (1964-1985), com a adesão à Doutrina de Segurança Nacional, acentuase a atuação das Forças Armadas no combate a um inimigo interno.

A transição entre o regime militar e o democrático no Brasil tem uma dinâmica particular. Devido a conflitos internos ao regime, decide-se iniciar um processo de abertura política. Este foi, portanto, feito pelos militares e para os militares de maneira lenta, gradual e segura. A maneira como se processou a transição brasileira permitiu aos militares a manutenção de muitas prerrogativas. Como resultado desse processo, a Constituição de 1988, assim como aponta Mathias, atribuiu às Forças Armadas as mesmas funções determinadas pela Constituição de 1967. Durante a década de 1990, percebe-se o estabelecimento de um padrão de emprego dos militares voltado cada vez mais para missões internas. Tem-se como exemplo o emprego do Exército na segurança da conferência Eco-92, em 1992; na Operação Rio, em 1994, cujo objetivo foi o combate ao narcotráfico; na contenção da greve dos petroleiros, em 1995, e dos policiais militares, em 1997 (ZAVERUCHA, 2005). Tal padrão confirma-se nos anos 2000, com a constante utilização dos militares na segurança de grandes eventos, ocupação de favelas, contenção de manifestações populares, entre outros (SAINT-PIERRE; DONADELLI, 2014). Deve-se destacar ainda a criação da 11ª Brigada de Infantaria Leve - Garantia da Lei e da Ordem, cujo objetivo é adestrar militares e produzir doutrina para as missões de garantia da lei e da ordem.

Apesar do direcionamento dado às Forças Armadas pelos governos brasileiros após o fim do regime militar no país, não se pode esquecer que durante os anos 1990 houve grande resistência por parte dos militares em assumir missões de segurança pública, justamente em resposta à política externa estadunidense para a região (SANTOS, 2004). Tal resistência coloca em questão o sucesso do discurso estadunidense no país, uma vez que, apesar de colocar em prática as indicações externas, a explicação para tanto se encontra menos em uma aceitação explícita delas do que em uma continuidade da

\footnotetext{
3 “(...) a Constituição de 1937, justamente por legalizar uma ditadura que tinha forte base militar, tolhe muitas das prerrogativas concedidas às Forças Armadas pelas Cartas de 1934 e 1891, aproximando-a da Constituição do Império, que concentrava os poderes nas mãos do Executivo" (MATHIAS; GUZZI, 2010, p. 46).
}

Conjuntura Global, vol. 5 n. 3, set./dez, 2016, p. 566 - 585 
identidade militar brasileira e na resistência dos fardados em perder suas prerrogativas findo o regime autoritário.

\section{CONSIDERAÇÕES FINAIS}

A busca estadunidense por homogeneizar estrategicamente a América Latina, após o fim do conflito Leste-Oeste, estabeleceu-se a partir de um discurso securitizador, cujo objetivo central foi ocupar as Forças Armadas da região com questões relacionadas ao tráfico de drogas ilícitas e ao crime organizado internacional. Porém, nos termos postos por Balzacq, o processo de securitização não ocorre pela simples execução do ato de fala. Ainda que este tenha poder de transformar a realidade, é limitado pelo contexto histórico em que é enunciado e pelas características e disposições da audiência que deve recebê-lo e anuir a ele. Os contextos argentino e brasileiro apresentavam características fortemente divergentes no momento em que o discurso estadunidense foi recebido, o que explica seus diferentes resultados. Partindo das categorizações de Haacke, a resposta argentina pode ser facilmente classificada como resistência explícita. O caso brasileiro oferece maior dificuldade à categorização. Ainda que tenha havido certa resistência à alocação dos meios militares para as missões de interesse explícito dos Estados Unidos, a identidade militar e a histórica concepção civil acerca do papel castrense no Estado mantiveram-se intactas com a transição para a democracia; não houve ímpeto por alterá-las, como no caso argentino. Os militares brasileiros negaram-se, durante esse processo, a abrir mão de suas prerrogativas históricas. Desse modo, entende-se aqui que, nas classificações empregadas por Haacke, o Brasil encontra-se entre a acomodação estratégica e a resistência. Por fim, defende-se que, nos casos analisados, as dinâmicas internas predominaram sobre os impulsos externos, sendo a variável determinante para a construção do atual padrão de emprego dos meios militares na Argentina e no Brasil.

\section{Referências}

BALZACQ, Thierry. The Three Faces of Securitization: Political Agency, Audience and Context, European Journal of International Relations, Vol. 11(2), 2005. p. 171-201.

BARRACHINA, C.; RIAL, J. Los ministerios de defenda em América Latina y las consecuencias de la multidimensionalidad de las amenazas. América Latina Hoy, v. 42, p. 131-159, 2006.

BERGER, Peter L.; LUCKMANN, Thomas. A Construção Social da Realidade. 30 ed. Petrópolis: Editora Vozes, 2009. 
BUZAN, Barry; WÆVER, Ole; WILDE, Jaap de. Security :a new framework for analysis. Boulder : Lynne Rienner, 1998.

FUCCILLE, L. A. As Forças Armadas e a temática interna no Brasil contemporâneo. 1999.162 f. Dissertação (Mestrado em Ciências Sociais) - Universidade Federal de São Carlos, São Carlos. 1999

GARCIA, Eugênio Vargas. O Pensamento dos militares em política internacional (19611989). Revista Brasileira de Política Internacional, v. 40 n.1, 1997. P. 18-40.

HAACKE, Jürgen; WILLIAMS, Paul. Regional Arrangements and Security Challenges: A Comparative Analysis, Crisis States Working Paper, 2009.

HERZ, M. . Política de segurança dos EUA para a América Latina após o final da Guerra Fria. Estudos Avançados (USP. Impresso) , São Paulo, v. 16, n.3, p. 85-104, 2002.

HUNTINGTON, Samuel P. The soldier and the state: The theory and politics of civil-military relations. Harvard University Press, 1957.

KOWER, Paul; LEGRO, Jeffrey. Norms, Identity and Their Limits: a theoretical reprise. In: KATZENSTEIN, Peter J. (org.). The Culture of National Security: Norms and Identity in World Politics. Nova York: Columbia University Press, 1996.

LÓPEZ, Ernesto. Argentina: um longo caminho ao controle civil sobre os militares. In: SAINT-PIERRE (Org.). Controle civil sobre os militares e política de defesa na Argentina, no Brasil, no chile e no Uruguai. São Paulo: Editora Unesp - Programa de PósGraduação em Relações Internacionais UNESP - UNICAMP - PUC/SP, 2007.

LÓPEZ, Ernesto. Nova problemática de segurança e "novas ameaças". In: MATHIAS, S. K. (Org.) ; SOARES, Samuel Alves (Org.) . Novas ameaças: dimensões e perspectivas. São Paulo: Sicureza, 2003.

MANAUT, R. B. Política exterior y seguridad hemisférica: diferencias y desencuentros. In: Isidro Sepúlveda. (Org.). Democracia y Seguridad en Iberoamérica. Los retos de la gobernabilidad. Madrid: Instituto Universitario "General Gutiérrez Mellado", 2006, p.37-64.

MATHIAS, Suzeley K. Brasil: interesse nacional e novas ameaças. In: Suzeley Kalil Mathias; Samuel Alves Soares. (Org.). Novas Ameaças: Dimensões e perspectivas. São Paulo: Sicurezza, 2003, v. , p. 125-156.

MATHIAS, S. K. ; GUZZI, André C . Autonomia na Lei: as Forças Armadas nas Constituições Nacionais. Revista Brasileira de Ciências Sociais (Impresso), v. 25, p. 41-57, 2010.

MEDEIROS FILHO, O. Entre a cooperação e a dissuasão: políticas de defesa e as percepções militares na América do Sul. Tese (Doutorado em Ciência Política) -

Faculdade de Filosofia, Letras e Ciências Humanas, Universidade de São Paulo, 2010.

MIGUEL, L. F. . Segurança e desenvolvimento: peculiaridades da ideologia da segurança nacional no Brasil. Dialogos Latinoamericanos, Aarhus (Dinamarca), v. 5, p. 40-56, 2002.

OBSERVATÓRIO SUL-AMERICANO DE DEFESA E FORÇAR ARMADAS. Informe Argentina $n^{o}$ 176-415. Disponível em: http://unesp.br/gedes/produtos/101/observatoriosudamericano-de-defensa-y-fuerzas-armadas/116/informe-semanal-argentina. Acesso em: 25 set. 2016.

OBSERVATÓRIO SUL-AMERICANO DE DEFESA E FORÇAR ARMADAS. Informe Argentina $n^{o} \quad 01 / 2011-41 / 2011$ Disponível em: http://unesp.br/gedes/produtos/101/observatorio-sudamericano-de-defensa-yfuerzas-armadas/116/informe-semanal-argentina. Acesso em: 25 set. 2016.

OBSERVATÓRIO SUL-AMERICANO DE DEFESA E FORÇAR ARMADAS. Informe Argentina $n^{o}$

$01 / 2012-45 / 2012$.

Disponível

em: 
http://unesp.br/gedes/produtos/101/observatorio-sudamericano-de-defensa-yfuerzas-armadas/115/informe-semanal-argentina-sul-americano. Acesso em: 25 set. 2016.

OBSERVATÓRIO SUL-AMERICANO DE DEFESA E FORÇAR ARMADAS. Informe Argentina $n^{o} \quad 01 / 2013-38 / 2013 . \quad$ Disponível em: http://unesp.br/gedes/produtos/101/observatorio-sudamericano-de-defensa-yfuerzas-armadas/115/informe-semanal-argentina-sul-americano. Acesso em: 25 set. 2016.

OBSERVATÓRIO SUL-AMERICANO DE DEFESA E FORÇAR ARMADAS. Informe Argentina $n^{o} \quad 01 / 2014-32 / 2014 . \quad$ Disponível em: http://unesp.br/gedes/produtos/101/observatorio-sudamericano-de-defensa-yfuerzas-armadas/115/informe-semanal-argentina-sul-americano. Acesso em: 25 set. 2016.

OBSERVATÓRIO SUL-AMERICANO DE DEFESA E FORÇAR ARMADAS. Informe Argentina $n^{o} \quad 01 / 2015-47 / 2015 . \quad$ Disponível em: http://unesp.br/gedes/produtos/101/observatorio-sudamericano-de-defensa-yfuerzas-armadas/115/informe-semanal-argentina-sul-americano. Acesso em: 25 set. 2016.

OBSERVATÓRIO SUL-AMERICANO DE DEFESA E FORÇAR ARMADAS. Informe Brasil $n^{o}$ 155-407. Disponível em: http://unesp.br/gedes/produtos/101/observatorio-sudamericanode-defensa-y-fuerzas-armadas/103/informe-semanal-brasil. Acesso em: 25 set. 2016.

OBSERVATÓRIO SUL-AMERICANO DE DEFESA E FORÇAR ARMADAS. Informe Brasil $n^{\circ}$ 01/2011-41/2011. Disponível em: http://unesp.br/gedes/produtos/101/observatoriosudamericano-de-defensa-y-fuerzas-armadas/102/informe-semanal-brasil-sul-americano. Acesso em: 25 set. 2016.

OBSERVATÓRIO SUL-AMERICANO DE DEFESA E FORÇAR ARMADAS. Informe Brasil $n^{\circ}$ 01/2012-45/2012. Disponível em: http://unesp.br/gedes/produtos/101/observatoriosudamericano-de-defensa-y-fuerzas-armadas/102/informe-semanal-brasil-sul-americano. Acesso em: 25 set. 2016.

OBSERVATÓRIO SUL-AMERICANO DE DEFESA E FORÇAR ARMADAS. Informe Brasil $n^{\circ}$ 01/2013-45/2013. Disponível em: http://unesp.br/gedes/produtos/101/observatoriosudamericano-de-defensa-y-fuerzas-armadas/102/informe-semanal-brasil-sul-americano. Acesso em: 25 set. 2016.

OBSERVATÓRIO SUL-AMERICANO DE DEFESA E FORÇAR ARMADAS. Informe Brasil $n^{\circ}$ 01/2014-42/2014. Disponível em: http://unesp.br/gedes/produtos/101/observatoriosudamericano-de-defensa-y-fuerzas-armadas/102/informe-semanal-brasil-sul-americano. Acesso em: 25 set. 2016.

OBSERVATÓRIO SUL-AMERICANO DE DEFESA E FORÇAR ARMADAS. Informe Brasil $n^{o}$ 01/2015-45/2015. Disponível em: http://unesp.br/gedes/produtos/101/observatoriosudamericano-de-defensa-y-fuerzas-armadas/102/informe-semanal-brasil-sul-americano. Acesso em: 25 set. 2016.

ROUQUIÉ, Alain . O Estado militar na América Latina. São Paulo: Alfa-Ômega, 1982.

SAIN, Marcelo F. Argentina: Democracia e Forças Armadas - entre a subordinação militar e os "defeitos civis". In: CASTRO, Celso (Org.) ; D'ARAUJO, Maria Celina (Org.) . Democracia e Forças Armadas no Cone Sul. Rio de Janeiro: Editora FGV, 2000.

SAIN, Marcelo Fabián. Las <<nuevas amenazas >> y las Fuerzas Armadas em la Argentina de los '90. XXIII International Congress Latin American Association (LASA), Washington, DC, United Estates, 2001. 
SAINT-PIERRE. As 'novas ameaças' às democracias latino-americanas: uma abordagem teórico-coneitual. In: Eliézer Rizzo de Oliveira. (Org.). Segurança \& Defesa Nacional. Da competição à cooperação regional. 1ed.São Paulo: Fundação Memorial, 2007.

SAINT-PIERRE, Héctor. 'Defesa'ou 'Segurança'? Reflexões em torno de Conceitos e Ideologias. Contexto Internacional, v.33, p. 407-433, 2011.

SAINT-PIERRE, Héctor Luis. El concepto de la seguridad muldimensional: una aproximación crítica. In: Sonia Alda Mejías; Verónica Gómez Ricaurte. (Org.). El concepto y las relaciones multilaterales de seguridad y defensa en el contexto de la UNASUR. 1ed.Madrid: Instituto Universitario General Gutiérrez Mellado - Ministéiro de Defensa Nacional del Ecuador, 2012, v. , p. 19-39.

SAINT-PIERRE, Héctor L. ; DONADELLI, Laura M. . Los temas más relevantes para la Defensa y las Fuezas Armadas en el Brasil durante 2013: un paso para adelante y dos para trás. Newsletter Resdal, 01 fev. 2014.

SANAHUJA, José Antonio; VERDES-MONTENEGRO, F. J. Seguridad y defensa en Suramérica: regionalismo, cooperación y autonomía en el marco de UNASUR. In: Serbin A., Martínez L. y H. Ramanzini (Org.). Anuario de la Integración de América Latina y el Gran Caribe, 2014, v. 10: 2013-2014.

SANTOS, Marcelo. O poder norte-americano e a América Latina no pós-Guerra Fria. São Paulo: Annablume, 2007.

SANTOS, Maria Helena C. A nova missão das Forças Armadas Latino-americanas no mundo pós-Guerra Fria: o caso do Brasil. Revista Brasileira de Ciências Sociais, v. 19, n. 54, fevereiro 2004. P 115-129.

SOARES, S. A. . Controles e autonomias: as Forças Armadas e sistema político brasileiro (1974-1999). 1. ed. São Paulo: Editora da Universidade Estadual Paulista - UNESP, 2006.

VITELLI, Marina. Argentina, Brasil y la defensa em América del Sur: las identidades estratégicas y la seguridad regional, Cuadernos política exterior argentina, 2015.

ZAVERUCHA, Jorge. FHC, Forças Armadas e Polícia: Entre o Autoritarismo e a Democracia. Rio de Janeiro: Ed. Record, 2005. v. 01. 285p 